Tomasz Nawracała ${ }^{1}$

Uniwersytet im. Adama Mickiewicza w Poznaniu Wydział Teologiczny

\title{
Kościół powszechny i Kościoły lokalne w nauczaniu papieża Franciszka
}

W roku 2018 mija pięć lat od wyboru Jorgego Bergoglia na stolicę św. Piotra w Rzymie. Wydaje się, że te minione lata pontyfikatu papieża z Argentyny domagają się podsumowania i bilansu, nie po to, by wypowiadać swoje oceny lub formułować ostateczne wnioski. Bardziej potrzebne jest zebranie wielu wątków, które stanowią istotną charakterystykę nauczania papieża Franciszka, oraz ich usystematyzowanie. W ten sposób można unikać trwania w zapatrzeniu w przeszłość lub wybiegania nieustannie w przyszłość, bez pogłębionego zastanowienia się nad tym, co dzieje się w teraźniejszości, w określonym czasie i miejscu.

Wśród wielu kwestii teologicznych, przewijających się w nauczaniu obecnego papieża, problematyka relacji Kościoła powszechnego do Kościołów lokalnych wydaje się szczególnie ważna i interesująca. Z jednej strony pojawia się ona w dokumentach o najwyższej randze papieskiego nauczania, a z drugiej wydaje się przekraczać dotychczasowe nauczanie Magisterium Kościoła. Analiza tytułowej kwestii niniejszego artykułu pojawi się dopiero w ostatniej jego części. Wcześniej wydaje się konieczne przypomnienie najważniejszych etapów współczesnej dyskusji na zagadnieniem oraz sformułowanie dwóch uwag metodologicznych, które rzucą światło na nauczanie samego papieża.

\section{Historia problematyki}

Pierwszy etap określenia relacji między Kościołem powszechnym a Kościołami lokalnymi przypada na początek XX wieku i dotyczy sprecyzowania znaczenia biblijnego pojęcia ekklesia. Słowo to określa najpierw wspólnotę, która mimo złożenia z wielu osób stanowi całość. Analizując nauczanie św. Pawła, można zauważyć podwójne użycie greckiego terminu. $Z$ jednej strony, we wszystkich po-

${ }^{1}$ Ksiądz dr hab. Tomasz Nawracała — adiunkt na Wydziale Teologicznym UAM w Poznaniu (ks.tomn@gmail.com). 
zdrowieniach otwierających listy Apostoł Narodów określa mianem ekklesia lokalne wspólnoty Kościoła. Z drugiej strony, kończąc swoje listy, apostoł ujawnia świadomość tego, że znajduje się jako sługa jedynego Kościoła złożonego z wielu ochrzczonych, w którym zawarta jest prawdziwa ekklesia tou Theou. Jeden jest Kościół wszystkich uczniów Chrystusa oraz jedna jest ekklesia, realizująca się we wspólnocie lokalnej wielu wierzących w Chrystusa w jednym miejscu.

Jaki sens pierwotny miał termin ekklesia? Jednym z pierwszych głosów w dyskusji były wyniki prac francuskiego badacza historii dogmatów Pierre'a Battifola. Według niego termin grecki stosowany był najpierw wobec różnych wspólnot lokalnych, aby następnie stać się terminem zbiorczym na określenie jednego Kościoła powszechnego ${ }^{2}$.

Inne podejście do problemu reprezentuje protestancki badacz dziejów Kościoła Adolf von Harnack. Odrzuca on pogląd liberalizmu protestanckiego, który głosił tezę o narodzinach Kościoła powszechnego na przełomie II i III wieku jako skutek postępującego zbliżenia Kościołów lokalnych. Harnack przeciwstawia się takim poglądom i głosi, że ekklesia ma w Nowym Testamencie znaczenie Kościoła uniwersalnego, choć tajemniczego i zbudowanego w niebie. Ostatecznie Kościoł powszechny oznacza Kościół doskonale zrealizowany w niebie, który w sposób niedoskonały i pojedynczy istnieje na ziemi we wspólnotach kościołów lokalnych ${ }^{3}$.

Jeszcze inne podejście do problemu reprezentuje Karl Ludwig Schmidt, autor hasła Kościół w słowniku Gerharda Kittla. Niemiecki egzegeta zauważa, że ekklesia ma w Piśmie Świętym sens biblijny, a nie świecki, to znaczy, że wskazuje na Boga. Chodzi przecież o ekklesia tou Theou. To wyrażenie jest synonimem określenia lud Boży. Jeśli św. Paweł zwraca się do określonej wspólnoty Kościoła, to nie zwraca się do tej wspólnoty lokalnej jako takiej, lecz do zgromadzenia Bożego, którym jest Kościół i który staje się obecny wszędzie tam, gdzie Bóg gromadzi swój lud ${ }^{4}$.

Wydaje się, że ostateczne rozwiązanie tego etapu dyskusji formułuje belgijski egzegeta Lucien Cerfaux. W swej książce La théologie de l'Église suivant s. Paul ${ }^{5}$ Cerfaux przedstawia następujące etapy ewolucji semantycznej pojęcia ekklesia. Po pierwsze, rozpoznanie pierwszorzędnego znaczenia wyrażenia ekklesia tou Theou. Wspólnota w Jerozolimie miała świadomość bycia resztą ludu, resztą Izraela. Stąd ta wspólnota lokalna łączy pojęcie quahal i ekklesia oraz odnosi je do siebie. Po drugie, w miarę ekspansji chrześcijaństwa poza Palestynę

${ }^{2}$ P. Battifol, L'Église naissante et le catholicisme, Paris 1909, s. 88n.

${ }_{3}$ A. von Harnack, Die Mission und Ausbreitung des Christentums in den ersten drei Jahrhunderten, Leipzig 1924, s. 420.

${ }^{4}$ K.L. Schmidt, ekklesia, w: Theologisches Wörterbuch zum Neuen Testament, hrsg. v. G. Kittel, Stuttgart 1938, Bd. 3, s. 502-539.

${ }^{5}$ L. Cerfaux, La théologie de l'Église suivant saint Paul, Paris 1948, s. 74-88 i 144-157. 
lud Boży konstytuuje się ze wspólnot albo mieszanych, grecko-żydowskich, albo tylko pogańskich. Na tym etapie trwa wciąż określenie wspólnoty w Jerozolimie jako ekklesia oraz pojawia się novum - wspólnota w Antiochii - i odnosi do siebie ten sam termin w sensie zgromadzenia lokalnego (por. Dz 11,26). Od tego momentu pojawia się podwójne użycie terminu ekklesia: w liczbie pojedynczej na wyrażenie zgromadzenia lokalnego oraz w liczbie mnogiej na całość zgromadzeń lokalnych. Wreszcie, po trzecie, termin ekklesia wraca do liczby pojedynczej, aby wyrazić całość ludu Bożego. Mimo dalszego rozwoju chrześcijaństwa każda wspólnota zakładana przez św. Pawła jest wspólnotą jedynej ekklesia tou Theou. Z tego powodu Kościół powszechny realizuje się w każdym Kościele lokalnym na skutek jednego zwołania i jednego zebrania ze strony Boga.

Drugi etap pojawia się w latach 90. minionego wieku. Jan Paweł II w przemówieniu do Kurii rzymskiej w grudniu 1990 roku przypomina najpierw o bogactwie Kościoła powszechnego, które opiera się na doświadczeniu wielu wspólnot lokalnych. Z drugiej strony Kościoły lokalne przynależą do Kościoła powszechnego, który w nich się zawiera i wyraża. Następnie papież stwierdza:

Ta wzajemność wyraża i umacnia godność obu stron, a jednocześnie ukazuje we właściwym świetle obraz Kościoła, jednego i powszechnego: znajduje on bowiem swe odzwierciedlenie i konkretną formę wyrazu w Kościołach lokalnych, „uformowanych na wzór Kościoła powszechnego, w których istnieje i z których się składa jeden i jedyny Kościół katolicki” (Lumen gentium 23). Z kolei także Kościoły lokalne są ex et in Ecclesia universali: w nim znajduje się ich źródło i z niego czerpią swą kościelność. Kościół lokalny jest Kościołem właśnie dlatego, że jest lokalną obecnością Kościoła powszechnego. Tak więc z jednej strony Kościół powszechny istnieje konkretnie w każdym Kościele lokalnym, w którym jest obecny i działa, z drugiej zaś, Kościół lokalny nie wyczerpuje całej głębi tajemnicy Kościoła, jako że nie wszystkie jej elementy konstytutywne dadzą się wyprowadzić z analizy samego tylko Kościoła lokalnego. Elementy te to urząd Następcy Piotra i Kolegium Biskupie ${ }^{6}$.

Myśl papieża opiera się na tezie o prawdziwej obecności Kościoła powszechnego w wielu Kościołach lokalnych. Podstawą tej obecności jest zależność wzoru i znaku między obu rzeczywistościami. Kościół powszechny jest wzorem dla Kościoła lokalnego, Kościół lokalny zaś jest znakiem Kościoła powszechnego. W ten sposób ukazuje się podwójna zależność:

Kościół powszechny jest $\mathbf{w}$ Kościołach i $\mathbf{z}$ Kościołów lokalnych oraz

Kościoły lokalne sa $\boldsymbol{z}$ Kościoła i $\boldsymbol{w}$ Kościele powszechnym.

Mimo wzajemnego oddziaływania na siebie i relacji warunkującej bycie, między Kościołem powszechnym a Kościołem lokalnym istnieje jednak różnica. Kościół powszechny okazuje się rzeczywistością głębszą i przekraczającą rozu-

\footnotetext{
${ }^{6}$ Jan Paweł II, Przemówienie do Kurii rzymskiej, OsRompl 12 (128) 1990, s. 20-21, tu: s. 21.
} 
mienie pojęcie ekklesia w warunkach ściśle geograficznych i socjo-politycznych. Kościół lokalny ma swego biskupa, który jest nie tylko głową określonej wspólnoty uczniów Chrystusa, lecz także należy do kolegium biskupiego. A to kolegium ma swoją widzialną głowę - papieża, który jest następcą św. Piotra ${ }^{7}$. Tych dwóch elementów, konstytutywnych dla Kościoła z woli samego Chrystusa, nie można ani pomijać, ani pomniejszać. Raczej należy je tak podkreślać, aby zachować istotę Kościoła.

Jeszcze bardziej radykalne stwierdzenia znajdują się w piśmie Kongregacji Nauki Wiary zatytułowanym List o niektórych aspektach Kościoła pojętego jako komunia (Communionis notio). Dokument, który opublikowano w 1992 roku, zawiera między innymi następujące sformułowania:

Kościół powszechny nie może być rozumiany jako suma Kościołów lokalnych ani jako federacja Kościołów partykularnych. Kościół nie jest wynikiem ich komunii, ale w swoim istotnym misterium jest rzeczywistością ontologicznie i czasowo uprzednią w stosunku do każdego pojedynczego Kościoła partykularnego.

Dalej Kongregacja wyjaśnia, że Kościół powszechny, który jest jeden i jedyny, spełnia się przez zradzanie Kościołów lokalnych. W tych lokalnych wspólnotach cały się także wyraża, będąc wobec nich źródłem. Kościół w Wieczerniku zebrany w dniu Pięćdziesiątnicy jest już powszechny, ponieważ objawia się wobec apostołów, jako przyszłych założycieli Kościołów lokalnych. W tym kontekście watykański dokument stwierdza:

Z tego Kościoła, który narodził się i został objawiony jako powszechny, wzięły początek różne Kościoły lokalne jako poszczególne realizacje jednego i jedynego Kościoła Jezusa Chrystusa. Rodząc się $w$ [Kościele powszechnym] i $z$ Kościoła powszechnego, w nim i z niego czerpią swoją eklezjalność. Dlatego wyrażenie Soboru Watykańskiego II: Kościót w Kościołach i z Kościołów (Ecclesia in et ex Ecclesiis), jest nieodłączne od drugiego: Kościoły w Kościele i z Kościoła. Jest oczywiste, że ten związek między Kościołem powszechnym i Kościołami partykularnymi ma misteryjny charakter; jest on nieporównywalny ze związkiem, jaki zachodzi między całością i częściami w jakiejkolwiek grupie czy społeczności czysto ludzkiej.

Każdy wierny przez wiarę i Chrzest jest włączony w jeden, święty, katolicki i apostolski Kościół. Nie należy się do Kościoła powszechnego za pośrednictwem, poprzez przynależność do Kościoła partykularnego; należy się w sposób bezpośredni, nawet jeśli wejście do Kościoła powszechnego i życie w nim urzeczywistniają się w sposób konieczny $w$ Kościele partykularnym ${ }^{8}$.

${ }^{7}$ Samo bycie widzialną głową nie przekreśla fundamentalnego oddziaływania Chrystusa jako Głowy Mistycznego Ciała.

${ }^{8}$ Tekst podaję za: Kongregacja Nauki Wiary, List o niektórych aspektach Kościoła pojętego jako komunia (Communionis notio) [w:] W trosce o petnię wiary. Dokumenty Kongregacji Nauki Wiary 1966-1994, red. J. Królikowski, Z. Zimowski, Tarnów 2010, s. 470-483, tu: s. 475-476. 
Wniosek, jaki można wysunąć z tekstu watykańskiej Kongregacji jest jeden: Kościół powszechny uprzedza ontologicznie i chronologicznie wszystkie Kościoły lokalne. Poza tym sama powszechność Kościoła jest czymś autentycznie obecnym i ukazującym się od dnia Pięćdziesiątnicy w osobach apostołów, którzy są w Wieczerniku reprezentantami różnych (choć przyszłych czasowo) Kościołów lokalnych.

Trzeci etap w dyskusji nad omawianym tematem dotyczy okresu po 1992 roku i związany jest z reakcją na dokument Kongregacji. Nie był on przyjęty bez słów krytyki, a główne napięcie wyraża się w debacie między Walterem Kasperem a Josephem Ratzingerem ${ }^{9}$. Debata trwała na przełomie tysiącleci (lata 19992000) i ostatecznie została przerwana, ale nie zakończona. Zabrakło wypracowania jednego stanowiska, które byłoby wspólne dla obu rzymskich purpuratów.

Czego dotyczyła istota sporu? Rozumienia sformułowania o ontologicznej i chronologicznej uprzedniości Kościoła powszechnego wobec Kościoła lokalnego. Według Kaspera tego typu teza jest nieprawdziwa, ponieważ Kościół powszechny nie istnieje sam w sobie, lecz jest raczej tworem abstrakcyjnym. Kościół powszechny istnieje tylko we wspólnocie Kościoła lokalnego, który siebie odkrywa jako lokalny i powszechny jednocześnie. Zatem Kościół powszechny i Kościół lokalny istnieją wyłącznie symultanicznie. Co więcej Kasper argumentuje, że biskup, na mocy święceń, jest odpowiedzialny za Kościół lokalny z upoważnienia samego Chrystusa, króla i pasterza. Na mocy władzy święceń, w jurydycznej jedności z biskupem Rzymu, każdy biskup jest reprezentantem Chrystusa w Kościele lokalnym, za który odpowiada i któremu przewodzi.

Linia argumentacji prezentowana przez Ratzingera opiera się na założeniu, że Kościół nie jest najpierw lub najbardziej zgromadzeniem ludzi (wymiar horyzontalny), lecz zjednoczeniem ludzi z Bogiem (wymiar wertykalny). Ten aspekt jest konieczny, jeśli chce się mówić prawdziwie o Kościele, a nie o grupie ludzi podzielających te same poglądy. Dlatego czasowe pierwszeństwo Kościoła ma swoje uzasadnienie w zamyśle Boga: On chciał Kościoła i dlatego podjął dzieło stworzenia ${ }^{10}$. Pierwszeństwo ontologiczne zaś wynika z tajemnicy zstąpienia Ducha Świętego na apostołów w Wieczerniku. Reprezentowali oni wszystkie narody na ziemi i nie stanowili fundamentu wyłącznie Kościoła w Jerozolimie, lecz

${ }^{9}$ Pierwszą otwartą krytykę wobec Communionis notio podjął W. Kasper w wykładzie wygłoszonym w 1993 roku w Cambridge. Wykład nosił tytuł: Church as Communion (tekst w: „New Blackfriars" 74 (1993) 871, s. 232-244), choć prezentowane w nim tezy znajdują się już w: Kirche als Communio: Überlegungen zur ekklesiologischen Leitidee des Zweiten Vatikanischen Konzils [w:] Die bleibende Bedeutung des Zweiten Vatikanischen Konzils, hrsg. v. F. König, Düsseldorf 1986, s. 62-84. Na temat samej debaty zob: K. McDonnelle, The Ratzinger/Kasper Debate: the Universal Church and Local Churches, „Theological Studies” 63 (2002), s. 227-250.

${ }^{10}$ To jest myśl Lumen gentium 2. Tekst za: Sobór Watykański II, Konstytucje, dekrety, deklaracje, Poznań 2008. 
Kościoła powszechnego. Za taką interpretacją wydarzenia opisanego w Dziejach Apostolskich przemawia dalsza historia apostołów, a szczególnie ich posługa głoszenia słowa Bożego, udzielania sakramentu chrztu oraz zachowywanie identycznego wyznania wiary.

Konsekwencje sporu są przynajmniej dwie. Dla Waltera Kaspera przyjęcie tezy o pierwszeństwie ontologicznym i czasowym Kościoła powszechnego jest potwierdzeniem tendencji do centralizacji Kościoła i uczynienia z kurii rzymskiej swoistego centrum dowodzenia. Rzymowi przyznaje się władzę decydowania o wszystkim i rozstrzygania różnych kwestii ponad i poza ich historyczno-egzystencjalnym odniesieniem. Innymi słowy decyzje kurii są często pozbawione wymiaru pastoralnego.

Według Josepha Ratzingera niewłaściwe ujęcie relacji Kościół powszechny i Kościoły lokalne prowadzi do rozpatrywania ich związku wyłącznie w kategoriach jurydycznych i zastanawiania się, kto nad czym ma władzę i komu co podlega. Ostatecznie zaś do uznania, że jedynym właściwym Kościołem, to znaczy Kościołem powszechnym, jest Kościół w Rzymie z jego instytucjami. Taki punkt patrzenia na omawianą kwestię jest zaś daleki od wizji Lumen gentium ${ }^{11}$.

\section{Uwagi metodologiczne}

Naszkicowana historia interpretacji relacji Kościół powszechny a Kościoły lokalne ma swoje konsekwencje w nauczaniu obecnego papieża. W tym miejscu warto jeszcze zaznaczyć dwie uwagi metodologiczne, które pozwolą na głębsze zrozumienie przedstawianego tematu.

Najpierw rola papieża. Dla Franciszka wybór na stolicę św. Piotra jest wyborem, który ma podwójne znaczenie. Kardynałowie Kościoła rzymskokatolickiego wybierają biskupa diecezji rzymskiej, który — jedyny w całym kolegium biskupim — jest wybierany, a nie nominowany ${ }^{12}$. Jednocześnie ten sam biskup pełni funkcję następcy św. Piotra i jest głową całego kolegium biskupiego. W tym kolegium odgrywa on rolę szczególną, to znaczy stanowi „trwałą i widzialną zasadę i fundament jedności wiary i komunii"'13. Papież, podobnie jak inni następcy apostołów, jest pasterzem, który prowadzi, umacnia i zarządza Kościołem Bożym ${ }^{14}$. Swoją misję spełnia jako członek kolegium biskupiego, mając pełną

11 Por. J. Ratzinger, The Local Church and the Universal Church, „America. The Jesuit Review", November 19 2001, [online] https://www.americamagazine.org/issue/351/local-church-and-universal-church [14.03.2018].

12 Por. Przemówienie po wyborze, OsRompl 5 (352) 2013, s. 3; Spotkanie z dziennikarzami 16.03.2013, OsRompl 5 (352) 2013, s. 12-13, tu: s. 13. Papież wyjaśnia dziennikarzom pochodzenie imienia, które przyjął Biskup Rzymu.

${ }^{13}$ LG 18 i 23.

${ }^{14}$ Por. LG 20. 
łączność z innymi biskupami. Zasada absolutnej jedności z wszystkimi następcami apostołów jest warunkiem koniecznym do wykonywania władzy otrzymanej od Chrystusa i należy ją interpretować zarówno jako jedność na linii papież-biskupi, jak i na linii biskup-biskup ${ }^{15}$. W takim zjednoczonym kolegium papież ma dodatkowo władzę prymatu, czyli z woli samego Chrystusa jest Jego zastępcą oraz Pasterzem Kościoła powszechnego. Samo kolegium biskupie, jednocześnie powszechne i różnorodne ${ }^{16}$, gromadzi się pod jedną głową, aby widzialnie ukazywać jedność całego Kościoła Chrystusowego. Z papieżem i pod zwierzchnictwem papieża każdy biskup spełnia otrzymane od Chrystusa funkcje, mając na uwadze dobro swoich wiernych oraz całego Kościoła ${ }^{17}$. Kolegium biskupie w każdym ze swoich członków ma „obowiązek umacniać i strzec jedności wiary i wspólnej dyscypliny całego Kościoła [...], aby wzrastała wiara i światło pełnej prawdy zajaśniało wszystkim ludziom"18. To jest wielka odpowiedzialność! Dlatego biskupi nigdy nie zostają sami, lecz spełniają ten obowiązek z pomocą Ducha Świętego, który „umacnia strukturę i zgodę”

Według Franciszka rola papieża ogranicza się wyłącznie do posługi miłości. Przewodzenie w miłości jest definicją Kościoła w Rzymie ${ }^{20}$ i streszcza rolę, jaką

${ }^{15}$ Lumen gentium wyjaśnia, że owa jedność całego Kościoła wynika z jedności z Chrystusem i przejawia się w wyznaniu wiary, sakramentach, zwierzchnictwie kościelnym oraz wspólnocie (communio); LG 14.

16 Por. LG 22.

17 Por. tamże.

18 LG 23.

19 LG 22.

${ }^{20}$ Samo wyrażenie zaczerpnięte jest z Listu do Rzymian św. Ignacego z Antiochii. Franciszek, zwracając się do nowych kardynałów, wyjaśnia: „Jesteście «podstawą» i jesteście inkardynowa$n i$ do Kościoła Rzymu, który «przewodzi całemu zgromadzeniu miłości» (Sobór Wat. II, Konst. dogm. o Kościele Lumen gentium 13; por. św. Ignacy Antiocheński, List do Rzymian, Prolog). W Kościele każde przewodniczenie wywodzi się z miłości, powinno być sprawowane w miłości i ma na celu miłość. Także w tym Kościół, który jest w Rzymie, odgrywa rolę przykładną: tak jak on przewodzi w miłości, tak każdy Kościół partykularny jest wezwany, aby na swoim terytorium przewodzić w miłości”. Alokucja na rozpoczęcie Konsystorza 14.02.2015, OsRompl 2 (369) 2015, s. 32-34, tu: s. 32. Już w zakończeniu przemówienia papież ponownie wraca do motywów przewodzenia w miłości, jednak tym razem odnosi je do całego Kościoła; tamże, s. 34. Jeszcze lepsze wyjaśnienie znajdujemy w przemówieniu wygłoszonym z racji powstania instytucji synodu biskupów. Franciszek stwierdza w nim, że papież nie jest ponad Kościołem: z racji chrztu jest jak każdy inny wierzący, a z racji święceń jak każdy inny biskup. Spełnia swoją rolę przewodniczenia w miłości wobec innych Kościołów, dodatkowo będąc sukcesorem Piotra Apostoła. Zob. Przemówienie podczas uroczystości upamiętniajacej 50. rocznicę ustanowienia Synodu Biskupów 17.10.2015, OsRompl 11 (377) 2015, s. 4-7, tu: s. 7. Por. także: Homilia Msza św. 'pro eligendo Papa', 12.03.2013, OsRompl 5 (352) 2013, s. 6-7, tu: s. 7; Audiencja 20.06.2013, OsRompl 8-9 (354) 2013, s. 38-39; List do Zgromadzenia Plenarnego Papieskiej Rady ds. Popierania Jedności Chrześcijan 20.11.2014, [online] http://w2.vatican.va/content/francesco/it/letters/2014/documents/papa-francesco_20141120_lettera-plenaria-unita-cristiani.html [15.03.2018]; Anioł Pański 26.05.2013, OsRompl 7 (353) 2013, s. 54. 
biskup Rzymu sprawuje wobec wspólnot Kościołów lokalnych. Miłość wyklucza osobistą pychę i zachęca do codziennego podejmowania drogi uniżenia na wzór Chrystusa. Stąd prawdziwy autorytet Kościoła w Rzymie wynika wyłącznie z miłości Chrystusa i tylko ona nadaje mu charakter powszechny i wiarygodny wobec ludzi i świata. Miłość jest centrum prawdy i staje się punktem konstrukcyjnym wspólnoty i jedności całej ludzkości przez to, że nie służy ani budowaniu murów, ani podziałom lub wykluczeniom ${ }^{21}$. Miłość Kościoła w Rzymie służy jedności i powszechności ${ }^{22}$. Tak swoją rolę określa Franciszek, zwracając się do biskupów amerykańskich: „mówię do was jako Biskup Rzymu, już w podeszłym wieku powołany przez Boga z ziemi, która także jest amerykańska, aby strzec jedności Kościoła powszechnego i wspierać w miłości drogę wszystkich Kościołów partykularnych, aby postępowały w poznaniu, wierze i umiłowaniu Chrystusa" ${ }^{23}$. Sama miłość łączy się z wyznawaniem wiary i świadectwem życia: „miłość jest właśnie wyrazem wiary, a także wiara jest wyjaśnieniem i podstawą miłości’”24.

Urząd św. Piotra jest urzędem rozpatrywanym jako posługiwanie innym w miłości. Takie zobowiązanie czyni stolicę w Rzymie wyjątkową w stosunku do innych wspólnot eklezjalnych, które od Rzymu powinny uczyć się również działania w miłości. Franciszek wyjaśnia, że:

Idąc szlakiem wytyczonym przez moich poprzedników, pragnę potwierdzić w tym miejscu, że „we wspólnocie kościelnej (in ecclesiastica communione) prawomocnie istnieją Kościoły partykularne, korzystające z własnych tradycji. Pozostaje przy tym nienaruszony prymat Stolicy Piotrowej, która przewodzi całemu zgromadzeniu miłości, sprawuje opiekę nad prawowitymi odrębnościami, a jednocześnie czuwa, aby nie przeszkadzały one jedności, lecz raczej jej służyły" (Lumen gentium 13). Owszem, prawdziwa różnorodność, uprawniona różnorodność, ta, która pochodzi z natchnienia Ducha, nie szkodzi jedności, ale jej służy; Sobór mówi nam, że ta różnorodność jest konieczna do jedności! 25 .

Istniejąca różnorodność między lokalnymi wspólnotami podlega władzy papieskiej, która musi być tak sprawowana, aby tę różnorodność wykorzystać do budowania jedności. Zaistnieje ona tam, gdzie wpierw ujawni się służba wynikająca z miłości.

${ }^{21}$ Por. Przemówienie do Papieskiej Akademii Kościelnej 25.06.2015, [online] http://w2.vatican.va/content/francesco/it/speeches/2015/june/documents/papa-francesco_20150625_pontificia-accademia-ecclesiastica.html [15.03.2018].

${ }^{22}$ Przemówienie do wspólnoty Papieskiego Uniwersytetu Gregoriańskiego oraz instytutów stowarzyszonych 10.04.2014, OsRompl 5 (361) 2014, s. 25-26, tu: s. 25.

${ }_{23}$ Spotkanie z episkopatem Stanów Zjednoczonych Ameryki 23.09.2015, OsRompl 10 (376) 2015, s. 27-31, tu: s. 28.

${ }^{24}$ Aniot Pański 9.11.2014, OsRompl 12 (367) 2014, s. 51-53, tu: s. 51.

${ }_{25}$ Spotkanie z uczestnikami sesji plenarnej Kongregacji dla Kościołów Wschodnich 21.11.2013, OsRompl 1 (358) 2014, s. 27-28, tu: s. 27. 
Można już tutaj postawić pytanie: czy takie pojmowanie prymatu nie jest jego samoograniczeniem? Czy papież nie odgrywa również roli umacniania w prawdzie, która nie mniej niż miłość służy budowaniu jedności całego Ciała Mistycznego?

Drugim elementem, na który warto zwrócić uwagę, jest preferowane stosowanie wyrażenia Kościół partykularny. Franciszek unika pojęcia Kościół lokalny i chyba nie jest to zabieg pozbawiony głębszego znaczenia. Wspomniany list Kongregacji wyjaśnia, że istnieje - niepoprawna i nieuzasadniona - tendencja do traktowania Kościoła partykularnego jako kompletnego podmiotu ${ }^{26}$. Kościół partykularny oznaczałby wspólnotę uczniów Chrystusa, która jest doskonała w sobie i jest już Kościołem bez konieczności odnoszenia się do innych wspólnot, aby od nich czerpać i innym służyć. Taka wspólnota ma, na mocy uposażenia ze strony Chrystusa w widzialną głowę — biskupa — prawo do rozstrzygania samodzielnie trudności i decydowania o kierunku postępowania. Kościół partykularny to Kościół charakteryzujący się nie tylko określonymi cechami wynikającymi z historyczno-społecznych uwarunkowań, lecz Kościół w pełnym znaczeniu samodzielny, a może nawet oddzielny. W ten sposób, jak słusznie zauważa Kongregacja, ujawnia się tendencja do uznania, że Kościół powszechny istnieje wyłącznie ,Z wzajemnego uznania się"27 pojedynczych wspólnot ${ }^{28}$. Wyrażenie Kościół lokalny ma zaś znaczenie zupełnie inne. Chodzi w nim o podkreślenie jednego i jedynego Kościoła, który realizuje się w określonym miejscu. Samo miejsce nie jest różnicujące dla Kościoła, ponieważ niczego nie dodaje do istoty Kościoła. Nadaje tylko Kościołowi Chrystusa ukonkretnienie w przestrzeni geograficznej, np. jako wyrażenie Kościół w Polsce lub Kościół w Poznaniu. Za każdym razem chodzi jednak o rzeczywistość eklezjalną większą i powszechną, a przede wszystkim trwałą 29 .

Wydaje się, że w swoim nauczaniu Franciszek mocno nawiązuje do poglądów Waltera Kaspera i właściwie powtarza jego opinie w dziedzinie nauki o Kościele. Czy były one niepoprawne? Nie. Czy były poprawne? Też nie. Raczej wyrażały prowadzone poszukiwania teologiczne i na tej płaszczyźnie powinny pozostać.

${ }^{26}$ Kongregacja Nauki Wiary, List..., 8, s. 474.

27 Tamże.

${ }^{28}$ Papież często posługuje się w swym nauczaniu obrazami. Jeden z nich pasuje w tym miejscu doskonale. Chodzi o owczarnię i pasterza, który idzie albo na przodzie, albo w środku, albo za stadem.

${ }^{29}$ Tu można się zastanawiać nad słowami: „wy wyrażacie głos Kościołów partykularnych, reprezentowanych na szczeblu Kościołów lokalnych przez Konferencje Episkopatów. Kościół powszechny i Kościoły partykularne są z ustanowienia Bożego; kościoły lokalne w ten sposób pojmowane są z ustanowienia ludzkiego", Przemówienie na rozpoczęcie obrad III Nadzwyczajnego Zgromadzenia Synodu Biskupów 6.10.2014, [online] http://w2.vatican.va/content/francesco/ pl/speeches/2014/october/documents/papa-francesco_20141006_padri-sinodali.html [14.03.2018]. 


\section{Idea Kościoła}

Przedstawiona szeroka perspektywa spojrzenia na relacje Kościół powszechny a Kościoły lokalne wydaje się i konieczna, i uzasadniona. Stanowisko Franciszka nie jest czymś zupełnie nowym, choć jednocześnie zamiast wyrażać jedność i powszechność tradycji i Magisterium, zdaje się ograniczać i skupiać na wybranych elementach.

Według Franciszka Kościół powszechny nie jest organizacją tylko społeczną, która ma za zadanie poprawiać życie ludzi ${ }^{30}$. Mimo zaangażowania w działalność charytatywną, opartą na chrześcijańskiej cnocie miłosierdzia, Kościół musi wciąż pozostawać wspólnotą uczniów Chrystusa. Taka wspólnota wpatruje się w Mistrza, rozważa Jego słowa i przekłada je na życie. Taka wspólnota daje nieustannie świadectwo wiary nie tylko w słowach, nauczając inne narody, lecz przede wszystkim w działaniu i pochylaniu się nad każdym bez wyjątku. Kościół powszechny żyje Ewangelią, żyje Chrystusem, świadczy o Nim i głosi Go światu. „Kościół bowiem, choć jest niewątpliwie również instytucją ludzką, historyczną, ze wszystkim, co to oznacza, nie ma natury politycznej, ale zasadniczo duchową; jest ludem Bożym, świętym ludem Bożym, który podąża na spotkanie z Jezusem Chrystusem. Jedynie w tej perspektywie można zdać sobie w pełni sprawę z tego, co czyni Kościół katolicki”31.

Podobnie czynią także Kościoły partykularne, choć ich głoszenie Ewangelii odpowiada warunkom ich istnienia. W tym ujawnia się nowość papieskiego nauczania. Jeśli wcześniej takie specyficzne warunki istnienia brano pod uwagę w związku z synodami biskupimi dla poszczególnych kontynentów lub regionów świata, to u Franciszka z góry należy zakładać niemożność stworzenia reguł uniwersalnych lub sposobów przykładania tych reguł do każdego Kościoła partykularnego. One są zbyt różne, aby móc je ujednolicić jednym prawem ${ }^{32}$.

Sama różnorodność i wielość Kościołów lokalnych ma swoje uzasadnienie dziejowe. Można przecież prześledzić historycznie powstawanie kolejnych wspólnot i to począwszy od Kościoła w Jerozolimie. Franciszek widzi w tej różnorodności przejaw działania Ducha Świętego:

${ }^{30}$ Por. Czuwanie modlitewne z okazji dnia ruchów, nowych wspólnot i stowarzyszeń kościelnych 18.05.2013, OsRompl 7 (353) 2013, s. 16-20, tu: s. 18; Spotkanie z młodzieża argentyńska 25.07.2013, OsRompl 8-9 (354) 2013, s. 8-9, tu: s. 8; Spotkanie z członkami komitetu koordynacyjnego CELAM 28.07.2013, OsRompl 10 (355) 2013, s. 25-29, tu: s. 26-28.

31 Spotkanie z dziennikarzami, s. 12.

32 Przedstawiając ideał biskupa, Franciszek stwierdza: „Nie możemy nigdy tracić z oczu potrzeb Kościołów partykularnych, które musimy zaspokajać. [...] wyzwaniem dla nas jest przyjmowanie punktu widzenia Chrystusa z uwzględnieniem tych szczególnych cech Kościołów partykularnych"; Przemówienie do uczestników zebrania Kongregacji ds. Biskupów 27.02.2014, OsRompl 3-4 (360) 2014, s. 24-27, tu: s. 25. 
Wasza dzisiejsza obecność, drodzy współbracia, jest znakiem, że komunia Kościoła nie oznacza jednolitości. [...] W Kościele różnorodność, która jest wielkim bogactwem, tworzy zawsze jedność w harmonii, niczym wielka mozaika, w której wszystkie elementy razem tworzą jeden wielki zamysł Boży. Powinno to pobudzać do przezwyciężania zawsze wszelkiego konfliktu raniącego ciało Kościoła. Zjednoczeni w różnorodności: nie ma innej katolickiej drogi do jedności. Taki jest duch katolicki, duch chrześcijański: jednoczenie się w zróżnicowaniu ${ }^{33}$.

Trzecia Osoba Trójcy Świętej została dana Kościołowi przez Chrystusa, aby jednoczyć to, co różne ${ }^{34}$. Przez Ducha Świętego Chrystus kieruje swoim Kościołem, gdyż tenże Duch „ze swoją życiodajną i jednoczącą siłą jest duszą Kościoła: czyni z wielu jedno ciało, mistyczne Ciało Chrystusa" ${ }^{35}$. Rola Ducha Świętego jest jednocześnie szersza. Według papieża Duch Święty daje Kościołowi odwagę do trwania tudzież do poszukiwania nowych sposobów głoszenia Ewangelii w świecie ${ }^{36}$. Takie działanie jest możliwe, ponieważ Duch utrwala w sercach uczniów Chrystusa Jego słowa - najważniejsze kryterium prawdy i ludzkiego działania. Wierność słowom Ewangelii oznacza nie tylko ich literalne wypełnianie, lecz również wnikanie „do wnętrza prawdy” i lepsze rozumienie spraw Bożych ${ }^{37}$. Cały proces rozpoznawania i przyjmowania prawdy nie dokonuje się w człowieku bez pomocy Bożej łaski. W ten sposób Kościół ukazuje się jako wspólnota łaski, która przemienia. Łaska zmienia i Kościół, i każdego z jego członków, a widać to szczególnie w budowaniu więzów jedności i komunii. Nawiązując do biblijnego opowiadania o wieży Babel, Franciszek mówi, że przeciwwagą dla tego wydarzenia był dzień Pięćdziesiątnicy. Jeśli w pierwszym wydarzeniu kluczowe były pycha i duma, skutkujące ostatecznie rozproszeniem ludzkości i pomieszaniem języków, to wydarzenie z Dziejów Apostolskich ukazuje właśnie jedność całej ludzkości kształtującą się ponad podziałami. Staje się to możliwe dzięki Duchowi Świętemu, który jednoczy ludzi w miłości bez barier i kontrastów, w miłości złączonej z pojednaniem i przebaczeniem ${ }^{38}$.

${ }^{33}$ Homilia 29.06.2013, OsRompl 8-9 (354) 2013, s. 39-41, tu: s. 40. Por. Spotkanie z uczestnikami sesji plenarnej ..., s. 27.

${ }^{34}$ Homilia Msza..., s. 7.

${ }^{35}$ Audiencja dla kardynałów 15.03.2013, OsRompl 5 (352) 2013, s. 10-11, tu: s. 11.

${ }^{36}$ Por. tamże. Zob. także: Audiencja generalna dla członków XIII Rady Zwyczajnej Sekretariatu Generalnego Synodu Biskupów 13.07.2013, OsRompl 8-9 (354) 2013, s. 31-32, tu: s. 31.

37 Audiencja generalna 15.05.2013, OsRompl 7 (353) 2013, s. 46-48, tu: s. 47.

38 Audiencja generalna 22.05.2013, OsRompl 7 (353) 2013, s. 48-50, tu: 49. Por. Audiencja generalna 19.06.2013, OsRompl 8-9 (354) 2013, s. 51-53, tu: s. 52. Idąc jeszcze dalej, Franciszek zauważa, że Kościół naznaczony jest ludzkimi słabościami, wadami i niedoskonałościami pasterzy i świeckich, także papieża. Zob. Audiencja generalna 29.05.2013, OsRompl 7 (353) 2013, s. 50-51, tu: s. 51. Podziały są według papieża najlepszą bronią diabła, aby zniszczyć Kościół lokalny i Kościół powszechny; por. Przemówienie do biskupów z terenów misyjnych 9.09.2016, OsRompl 10 (386) 2016, s. 42-43, tu: s. 43. Nawiązując do wieży Babel i tajemnicy Pięćdziesiątnicy, papież mówi: „Kościół nie rodzi się wyizolowany, rodzi się jako powszechny, jeden, katolicki, z tożsamością ustaloną, 
Budowaniu więzów jedności i komunii służą pasterze kościołów lokalnych. Ich podstawowym zadaniem jest nie tylko utrzymywać jedność z papieżem, lecz również strzec wielowymiarowości, która tworzy Kościół i przez którą Kościół się wyraża ${ }^{39}$. Każdy biskup powinien znać potrzeby powierzonego mu Kościoła lokalnego i troszczyć się, aby we właściwy sposób na nie odpowiedzieć. Odkrywanie tych potrzeb dokonuje się w kontemplacji i uważnej obserwacji życia ludu Bożego. Takie działanie pozwala szukać nowych sposobów ewangelizacji i misji, począwszy od różnych rzeczywistości parafialnych. W ten sposób także ogólna misja Kościoła powszechnego aktualizuje się w każdym Kościele lokalnym według jego własnych potrzeb ${ }^{40}$.

W tym miejscu należy przypomnieć dwie wypowiedzi papieża, które domagają się komentarza. Pierwsza pochodzi z adhortacji Evangelii gaudium:

Chętnie przyjąłem zaproszenie Ojców synodalnych do zredagowania tej adhortacji. Czyniąc to, przejmuję bogactwo prac Synodu. Poprosiłem także o radę wielu osób, a ponadto mam zamiar podzielić się troskami, jakich doświadczam w tym konkretnym momencie dzieła ewangelizacyjnego Kościoła. Istnieje bardzo wiele tematów związanych z ewangelizacją współczesnego świata, które można by tu rozwinąć. Zrezygnowałem jednak ze szczegółowego omówienia tych licznych kwestii, które powinny być przedmiotem badań i starannego pogłębienia. Nie uważam także, że należy oczekiwać od papieskiego nauczania definitywnego lub wyczerpującego słowa na temat wszystkich spraw dotyczących Kościoła i świata. Nie jest rzeczą stosowną, żeby Papież zastępował lokalne Episkopaty w rozeznaniu wszystkich problemów wyłaniających się na ich terytoriach. W tym sensie dostrzegam potrzebę przyjęcia zbawiennej „decentralizacji”"41.

Franciszek zauważa przede wszystkim bogactwo głosów wyrażone podczas prac ojców synodalnych. Ich głos traktuje jako ważny, choć nie jedyny. Tekst adhortacji powstaje na podstawie głosu biskupów, innych osób oraz przemyśleń samego papieża. Nie jest to nic zaskakującego, bo zarówno temat, jak i metoda pracy domagały się szerokiego spojrzenia i konsultacji nie tylko biskupów, ale także wiernych świeckich. Papież, jeszcze jako arcybiskup Buenos Aires, nie brał bezpośrednio udziału w obradach synodu na temat nowej ewangelizacji, który odbył się w Rzymie w 2012 roku. Nie było to konieczne, bowiem każdy synod kończy się listą wniosków przekazaną Benedyktowi XVI, z którą zapoznał się zapewne i sam Franciszek. Ten ostatni jednak nie podejmuje szczegółowego omówienia tematów związanych z ewangelizacją i stwierdza, że nie jest rolą namiestnika św. Piotra rozstrzygać w sposób definitywny i wyczerpujący sprawy dotyczące Kościoła i świata.

ale otwartą na wszystkich, nie zamkniętą, z tożsamością, która obejmuje cały świat, nie wykluczając nikogo"; Regina coeli 24.05.2015, OsRompl 6 (373) 2015, s. 50-51, tu: s. 50.

${ }^{39}$ Przemówienie do uczestników kongresu wikariuszy biskupich i delegatów biskupich ds. $\dot{z}$ cia konsekrowanego 28.10.2016, OsRompl 11 (387) 2016, s. 35-37, tu: s. 36.

40 Przemówienie do uczestników kongresu Międzynarodowego Forum Akcji Katolickiej 27.04.2017, [online] http://w2.vatican.va/content/francesco/it/speeches/2017/april/documents/papa-francesco_20170427_congresso-azione-cattolica.html [15.03.2018].

${ }^{41}$ Franciszek, Evangelii gaudium, Częstochowa 2014, 16. 
Mogą to robić konferencje biskupów, które mają zdecydowanie lepsze rozeznanie tematów i sposobów ich rozwiązania. Owszem, bez wątpienia nikt nie oczekuje od papieża rozwiązywania problemów świata. Niemniej sprawy Kościoła powszechnego nie mogą być pomijane i pozostawiane do rozwiązania innym. Właśnie na tym polega rola biskupa Rzymu, który razem z biskupami zebranymi cum Petro i sub Petro wypowiada się w sposób definitywny w sprawach wiary i moralności. Druga, $\mathrm{z}$ adhortacji Amoris laetitia:

Proces synodalny pozwolił podjąć refleksję nad sytuacją rodzin w dzisiejszym świecie, poszerzyć nasze spojrzenie i ożywić naszą świadomość znaczenia małżeństwa i rodziny. Jednocześnie złożoność omawianych tematów ukazała nam potrzebę dalszego, otwartego pogłębienia niektórych zagadnień doktrynalnych, moralnych, duchowych i duszpasterskich. Refleksja pasterzy i teologów, jeśli jest wierna Kościołowi, związana z rzeczywistością i twórcza, pomoże nam osiągnąć większą jasność. Dyskusje, jakie mają miejsce w środkach przekazu lub w publikacjach, czy też pomiędzy ludźmi Kościoła, przebiegają od niepohamowanej chęci zmiany wszystkiego, pozbawionej wystarczającej refleksji i ugruntowania, do postawy usiłowania rozstrzygnięcia wszystkiego za pomocą ogólnych norm lub wyciągania daleko idących wniosków z niektórych refleksji teologicznych.

Przypominając, że „czas jest ważniejszy niż przestrzeń”, pragnę podkreślić, iż nie wszystkie dyskusje doktrynalne, moralne czy duszpasterskie powinny być rozstrzygnięte interwencjami Magisterium. Oczywiście, w Kościele konieczna jest jedność doktryny i działania, ale to nie przeszkadza, by istniały różne sposoby interpretowania pewnych aspektów nauczania lub niektórych wynikających z niego konsekwencji. Będzie się tak działo, aż Duch nie doprowadzi nas do całej prawdy (por. J 16,13), to znaczy, kiedy wprowadzi nas w pełni w tajemnicę Chrystusa i będziemy mogli widzieć wszystko Jego spojrzeniem. Poza tym, w każdym kraju lub regionie można szukać rozwiązań bardziej związanych z inkulturacją, wrażliwych na tradycje i na wyzwania lokalne. Ponieważ „kultury bardzo różnią się między sobą i każda ogólna zasada [...] potrzebuje inkulturacji, jeśli ma być przestrzegana i stosowana w życiu”"42.

Wypowiedź papieża ponownie przypomina o konieczności podjęcia wielowątkowej refleksji nad sytuacją rodziny we współczesnym świecie. Ludzka rodzina to wspólnota osób, które podejmują trud życia na wzór samego Chrystusa, aby w ten sposób móc osiągnąć zbawienie. Temu zbawieniu podporządkowana jest działalność Kościoła, który dąży do rozpatrywania doczesności w świetle Ewangelii. Cel jest wciąż przed Kościołem i chociaż pozostaje on darem ze strony Boga, można do niego się przybliżać, przyjmując prawdę proponowaną przez Ducha Świętego. Jeśli Duch Święty jest gwarantem i strażnikiem prawdy, jednej i jedynej, bo objawionej, to jak może ujawniać się w pluralizmie interpretacji, nauczania lub działania? Tymczasem to sugeruje wypowiedź papieża, kiedy stwierdza on, że nie wszystkie dyskusje doktrynalne, moralne czy duszpasterskie powinny być rozstrzygane przez Urząd Nauczycielski Kościoła. Innymi słowy papież uznaje, że większe rozeznanie we wspomnianych dziedzinach mają inne instytucje niż to, co dotąd traktowano jako centrum Kościoła - kuria rzymska z jej instytucjami. Jednakże Magisterium

${ }^{42}$ Franciszek, Amoris laetitia 2-3, Kraków 2016. 
Kościoła ma wymiar dużo szerszy. II sobór watykański w konstytucji dogmatycznej o Kościele wyraźnie zaznacza, że misja nauczania spoczywa na całym kolegium biskupów, którzy trwają w jedności z głową kolegium. Na bazie tej jedności i kolegialności ujawnia się Urząd Nauczycielski. Tam, gdzie brakuje któregoś z elementów, nie może pojawić się autentyczny Urząd Nauczycielski. W konsekwencji Lumen gentium przestrzega każdego biskupa przed głoszeniem własnej Ewangelii. Biskup jest jej dysponentem a nie autorem; on ją przekazuje, a nie pisze. Co więcej, sama jedność kolegium apostolskiego gwarantuje nieomylność depozytu wiary. Lud Boży nie błądzi w wierze, nie dlatego, że jest do tego zdolny sam z siebie, tylko dlatego, że ma wśród siebie właściwie ukształtowanych pasterzy. Oni razem z ludem słuchają Ewangelii, oni jej strzegą i oni ją wprowadzają w życie. Na każdym z tych etapów cieszą się także asystencją Ducha Świętego, tego, który dopełnia misję Chrystusa.

Jeśli jedność kolegium z biskupem Rzymu i między sobą uznać za wartość nadrzędną dla całego Kościoła, to propozycja wolności w interpretacji kwestii doktrynalnych, moralnych lub duszpasterskich rodzi sporą trudność. Gdyby chodziło tylko o kwestie duszpasterskie, to propozycję Franciszka można by jeszcze zaakceptować. Ostatecznie przecież w każdym kraju istnieją rozmaite tradycje pastoralne, które pielęgnowane nie wpływają na jedność Kościoła. Jednak podobne traktowanie kwestii doktrynalnych i moralnych niesie wielkie niebezpieczeństwo: wolności w interpretacji oraz różnic w interpretacji ${ }^{43}$.

Samodzielne decydowanie o doktrynie lub moralności przez Kościoły lokalne bez odniesienia do innych wspólnot kościelnych prowadzi do pytań: czy Kościół Chrystusowy w ogóle istnieje na ziemi? Czy zniknął na skutek podziałów uczniów Chrystusa? A może w ogóle nie istniał i wciąż czeka się na jego ukazanie się w czasach ostatecznych? Czy poszczególne Kościoły lokalne są jednym i jedynym Kościołem Chrystusa jako całość, razem? Czy może mogą trwać niezależnie, realizując samodzielnie elementy eklezjotwórcze: przepowiadanie słowa, posługę ministerialną i sakramenty? Jaką rolę wówczas będzie odgrywał papież i co z kolegialnością następców apostołów? Trzeba nieustannie pamiętać, że dzień Pięćdziesiątnicy jest dniem szczególnym dla wspólnoty uczniów Chrystusa. Otrzymują oni

${ }^{43}$ Podobne stwierdzenie znajdujemy w dokumencie Międzynarodowej Komisji Teologicznej. W tekście opublikowanym w marcu 2018 roku, rozpatrując kwestię synodalności, wskazuje się na trzy przejawy Kościoła synodalnego, które się współprzenikają: consensus fidelium, kolegialność biskupów i prymat Piotra. Na tej podstawie Kościół może, zachowując depositum fidei i twórczą otwartość na Ducha Świętego, odpowiedzieć na szczególne okoliczności i zmiany. W ten sposób można słuchać wszystkich (ciekawe, że dokument używa słowa soggetti, a nie persone czyżby porzucano język personalizmu?), którzy formują lud Boży, i razem rozeznawać prawdę. Czyżby prawda nie była jeszcze dana Kościołowi w objawieniu? Zob. Międzynarodowa Komisja Teologiczna, La sinodalità nella vita e nella missione della Chiesa, nr 94, [online] http://www. vatican.va/roman_curia/congregations/cfaith/cti_documents/rc_cti_20180302_sinodalita_it.html [20.10.2018]. 
depozyt wiary oraz misteria — sakramenty — które najpierw przyjmuje grono apostołów i które dalej będą przez nich przekazywane. W Wieczerniku rodzi się wspólnota służebna, która następnie stanie się wspólnotą społeczną, a jeszcze później także teologalną. W ten sposób grono dwunastu apostołów z Piotrem na czele staje się ontologicznym źródłem Kościoła i będzie utrwalane jako reguła w kolegium biskupów, które ma za głowę biskupa Rzymu. Taka jest struktura Kościoła, który jest apostolski i powszechny jednocześnie i który od początku jest czymś więcej niż tylko Kościołem lokalnym w Jerozolimie, Kościołem, od którego pochodzą inne Kościoły lokalne. Od apostolskiego Kościoła w Jerozolimie zależą inne Kościoły lokalne, co więcej, samo kolegium apostołów spełnia rolę uprzednią wobec poszczególnych wspólnot eklezjalnych. Ta rola wynika ze zradzania i utrzymywania eklezjalności lokalnej jako wspólnoty wiary. Kościół w Jerozolimie jako Kościół powszechny jest pierwszy i trwa w swej identyczności w każdej wspólnocie Kościoła lokalnego, nadając mu właśnie określoną realizację eklezjalną.

Pytania, które rodzą się pod wpływem papieskiego nauczania są liczne i trudno na nie udzielać szybkich odpowiedzi. Teolog ma jednak obowiązek takie pytania stawiać i zastanawiać się, jak dalece można reinterpretować dane tradycje pod wpływem zmieniającego się świata. Jako podsumowanie całej kwestii relacji Kościoła powszechnego i Kościołów lokalnych w nauczaniu Franciszka można stwierdzić, że istnieje między nimi więź boska — osoba Ducha Świętego. To ona spaja i utrzymuje Kościół mimo różnorodności. Istnieje także inna wieź — ludzka, oparta na uznaniu prymatu Piotra jako primus inter pares. Nauczanie Franciszka nie jest może do końca spójne, jedno i jednoznaczne, ale to już kolejne pokolenia ocenią, czy popełnił błąd, czy też okazał się prorokiem.

\section{The Universal Church and Local Churches in the Teaching of Pope Francis}

\section{Summary}

Mutual relations between the universal Church and local Churches belong to topics whose meaning increases and which return systematically in theological discussions. Hence also the short pontificate of Pope Francis is not deprived of certain elements that allow a different view of the issue of the liaison between the two ecclesial communities. The article presents Francis' view on the relationship between the universal Church and local Churches, showing the dependence of papal views on the theological thinking of Cardinal Walter Kasper. At the same time, two additional issues (Peter's primacy and the formulation of the particular Church) are indicated, which are important for the papal ecclesiology.

\section{Keywords}

Universal Church, local Church, Francis, community, Pope, relationship

\section{Słowa kluczowe}

Kościół powszechny, Kościół lokalny, Franciszek, wspólnota, papież, relacja 


\section{Bibliografia}

Battifol P., L'Église naissante et le catholicisme, Paris 1909.

Cerfaux L., La théologie de l'Église suivant saint Paul, Paris 1948.

Harnack A. von, Die Mission und Ausbreitung des Christentums in den ersten drei Jahrhunderten, Leipzig 1924.

Jan Paweł II, Przemówienie do Kurii rzymskiej, OsRompl 12 (128) 1990, s. 20-21.

Kasper W., Church as Communion, „New Blackfriars” 74 (1993) 871, s. 232-244.

Kasper W., Kirche als Communio: Überlegungen zur ekklesiologischen Leitidee des Zweiten Vatikanischen Konzils [w:] Die bleibende Bedeutung des Zweiten Vatikanischen Konzils, hrsg. v. F. König, Düsseldorf 1986, s. 62-84.

Kongregacja Nauki Wiary, List o niektórych aspektach Kościoła pojętego jako komunia (Communionis notio) [w:] W trosce o petnie wiary. Dokumenty Kongregacji Nauki Wiary 1966-1994, red. J. Królikowski, Z. Zimowski, Tarnów 2010, s. 470-483.

McDonnelle K., The Ratzinger/Kasper Debate: the Universal Church and Local Churches, „Theological Studies” 63 (2002), s. 227-250.

Międzynarodowa Komisja Teologiczna, La sinodalità nella vita e nella missione della Chiesa, 94, [online] http://www.vatican.va/roman_curia/congregations/cfaith/cti_documents/rc cti_20180302_sinodalita_it.html [20.10.2018].

Ratzinger J., The Local Church and the Universal Church, „America. The Jesuit Review” November 19 2001, [online] https://www.americamagazine.org/issue/351/local-church-and-universal-church [14.03.2018].

Schmidt K.L., [hasło] ekklesia [w:] Theologisches Wörterbuch zum Neuen Testament, hrsg. v. G. Kittel, Stuttgart 1938, Bd. 3, s. 502-539.

Sobór Watykański II, Konstytucje, dekrety, deklaracje, Poznań 2008.

\section{Teksty papieża Franciszka}

Alokucja na rozpoczęcie Konsystorza 14.02.2015, OsRompl 2 (369) 2015, s. 32-34.

Amoris laetitia, Kraków 2016.

Anioł Pański 26.05.2013, OsRompl 7 (353) 2013, s. 54.

Anioł Pański 9.11.2014, OsRompl 12 (367) 2014, s. 51.

Audiencja 20.06.2013, OsRompl 8-9 (354) 2013, s. 38-39.

Audiencja dla kardynatów 15.03.2013, OsRompl 5 (352) 2013, s. 10-11.

Audiencja generalna 15.05.2013, OsRompl 7 (353) 2013, s. 46-48.

Audiencja generalna 22.05.2013, OsRompl 7 (353) 2013, s. 48-50.

Audiencja generalna 29.05 2013, OsRompl 7 (353) 2013, s. 50-51.

Audiencja generalna 19.06.2013, OsRompl 8-9 (354) 2013, s. 51-53.

Audiencja generalna dla członków XIII Rady Zwyczajnej Sekretariatu Generalnego Synodu Biskupów 13.07.2013, OsRompl 8-9 (354) 2013, s. 31-32.

Czuwanie modlitewne $z$ okazji dnia ruchów, nowych wspólnot i stowarzyszeń kościelnych

18.05.2013, OsRompl 7 (353) 2013, s. 16-20.

Evangelii gaudium, Częstochowa 2014.

Homilia 29.06.2013, OsRompl 8-9 (354) 2013, s. 39-41.

Homilia Msza św. 'pro eligendo Papa', 12.03.2013, OsRompl 5 (352) 2013, s. 6-7. 
List do Zgromadzenia Plenarnego Papieskiej Rady ds. Popierania Jedności Chrześcijan 20.11.2014, [online] http://w2.vatican.va/content/francesco/it/letters/2014/documents/papa-francesco_20141120_lettera-plenaria-unita-cristiani.html [15.03.2018];

Przemówienie do biskupów z terenów misyjnych 9.09.2016, OsRompl 10 (386) 2016, s. 42-43.

Przemówienie do Papieskiej Akademii Kościelnej 25.06.2015, [online] http://w2.vatican.va/content/francesco/it/speeches/2015/june/documents/papa-francesco_20150625_pontificia-accademia-ecclesiastica.html [15.03.2018].

Przemówienie do uczestników kongresu Międzynarodowego Forum Akcji Katolickiej 27.04.2017, [online] http://w2.vatican.va/content/francesco/it/speeches/2017/april/documents/papa-francesco_20170427_congresso-azione-cattolica.html [15.03.2018].

Przemówienie do uczestników kongresu wikariuszy biskupich i delegatów biskupich ds. życia konsekrowanego 28.10.2016, OsRompl 11 (387) 2016, s. 35-37.

Przemówienie do uczestników zebrania Kongregacji ds. Biskupów 27.02.2014, OsRompl 3-4 (360) 2014, s. 24-27.

Przemówienie do wspólnoty Papieskiego Uniwersytetu Gregoriańskiego oraz instytutów stowarzyszonych 10.04.2014, OsRompl 5 (361) 2014, s. 25-26.

Przemówienie na rozpoczęcie obrad III Nadzwyczajnego Zgromadzenia Synodu Biskupów 6.10.2014, [online] http://w2.vatican.va/content/francesco/pl/speeches/2014/october/documents/papa-francesco_20141006_padri-sinodali.html [14.03.2018].

Przemówienie po wyborze, OsRompl 5 (352) 2013, s. 3.

Przemówienie podczas uroczystości upamiętniajacej 50. rocznicę ustanowienia Synodu Biskupów 17.10.2015, OsRompl 11 (377) 2015, s. 4-7.

Regina coeli 24.05.2015, OsRompl 6 (373) 2015, s. 50-51.

Spotkanie z członkami komitetu koordynacyjnego CELAM 28.07.2013, OsRompl 10 (355) 2013, s. $25-29$.

Spotkanie z dziennikarzami 16.03.2013, OsRompl 5 (352) 2013, s. 12-13.

Spotkanie z episkopatem Stanów Zjednoczonych Ameryki 23.09.2015, OsRompl 10 (376) 2015, s. 27-31.

Spotkanie z młodzieża argentyńska 25.07.2013, OsRompl 8-9 (354) 2013, s. 8-9.

Spotkanie z uczestnikami sesji plenarnej Kongregacji dla Kościołów Wschodnich 21.11.2013, OsRompl 1 (358) 2014, s. 27-28. 